\title{
Using Data to Enhance College Teaching: Course and Departmental Assessment Results as a Faculty Development Tool
}

\author{
Catherine M. Wehlburg \\ Texas Christian University
}

This chapter highlights the need for using assessment of student learning outcomes data to guide teaching-related faculty development decision-making. Literature on the topic suggests that using assessment results to inform faculty development discussions makes better use of both the assessment data and the time spent in faculty development. Feedback and consultations regarding feedback seem to be important variables in determining if changes in teaching will occur. Types of assessment data that may especially inform teaching-related conversations are discussed.

\section{INTRODUCTION}

Gaculty development (Gillespie, Hilsen, \& Wadsworth, 2002) and assessment (Huba \& Freed, 2000; Hutchings \& Marchese, 1990; Wchlburg, 2002) have been a part of education for a very long time. Faculty development is often considered to be the enhancement of teaching - thus improving student learning (Gillespie, Hilsen, \& Wadsworth, 2002; Wilcox, 1997), while assessment has typically focused on determining academic quality (Banta $\&$ Associates, 1993). But not until recently have those in higher education seen the importance of connecting faculty development and assessment of student learning outcomes together to form an even more powerful way to enhance reaching and learning. 
Gibbs (1999) identifies an interesting disparity between faculty acceptance of using data to modify research and grant-writing, but not teaching. "Imagine the impact on the quality of course design if no course would be funded to operate unless its plans had been through a competitive peer review exercise in which only one in six were approved" (p. 150). This scenario will, most likely, never occur, but it does highlight the differences in perception regarding use of data in teaching-related areas.

Since "teaching without learning is just talking" (Angelo \& Cross, 1993, p. 3), we need to know what a student has learned in order to understand what can be modified or enhanced in terms of teaching. In other words, without knowing what a student has learned, it is impossible to know if teaching has occurred. If what Cross (1993) has stated is true, "the ultimate criterion of good teaching is effective learning" (p. 20), it becomes essential to have appropriate assessment results in order to undertake any type of faculty development work with a particular faculty member.

While there are different organizational structures, most institutions of higher education have an individual or a committee that oversees institutional assessment and one that oversees faculty development. On smaller campuses, the oversight might come at the departmental level rather than the institutional level, but it is still possible to tap into the information that is available. Regardless of structure, the individual faculty member is the key to improving teaching. The faculty member must first recognize a desire to modify her or his teaching methods and then must have access to assessment information at the course level. By looking at student outcomes and comparing them to course objectives, faculty can have a good idea about where their focus for change needs to be. While this may be done by the faculty member, many faculty may choose to seek a colleague or a staff member from the teaching/learning center to help interpret existing data (course evaluations, results from classroom assessments, for example) or to gather data directly (SGIDs or focus groups with students) and then to suggest teaching modifications. But there is another source of data that should be accessed: student learning outcomes.

While faculty at most institutions see assessment as, at best, a mandated hassle, the assessment process is actually a rich source of data that can (and should) be mined at the course and departmental level for the explicit purpose of improving teaching and learning. Unfortunately, some faculty members distrust the concept of assessment because of its dual purpose, what Ewell (2002) has called the dilemma of purpose. Ewell states, "it has become commonplace in discussions of assessment over the past two decades, for example, to make the distinction between 'accountability' and 'improvement" (p. G). 
But using assessment data for improvement purposes is exactly what should be done in faculty development. In fact, according to Huba and Freed (2000), "the [assessment] process culminates when assessment results are used to improve subsequent learning" (p. 8). And, since in order to improve learning, a faculty member will, most likely, need to modify teaching methodologies, course design, or other instructional practices, assessment data must be used to inform the faculty development conversation. The types of data used for this conversation will, in part, be chosen based on individual faculty needs and the availability of resources. But many of these types of assessment results may already exist or be easily obtainable by the faculty member for use in modifying teaching.

\section{Trpes of Assessment Data}

Faculty should have access to a variety of outcomes measurements for student learning. While these may vary from department to department and institution to institution, the basic function is the same: information on how much and what type of learning students are gaining as a result of a course or program. Faculty can obtain these outcomes to see what areas of a course need specific attention.

\section{Course-Specific Measures}

Faculty may gain information regarding objectives and student learning in a specific course. This assessment data may or may not be used by the department to assess student learning, but it can give a great deal of information regarding a specific course to a faculty member and is necessary for understanding which parts of the course should be modified or retained. A faculty developer who is working with a faculty member with this type of data can help the faculty member better understand the areas of a course that need special attention. The advantage of these outcomes is that they are collected (in many cases) by the faculty member and give information about student learning (versus course evaluations or student satisfaction ratings). In some cases, the faculty developer may need to work with the faculty member to develop measures of student learning, but this can be done by taking already identified outcomes for a course or unit and then matching those with a student work product (answers on an exam or paper, or from another classroom assessment technique) through an analysis of course documents (Bers, Davis, \& Taylor, 2000), or peer review of teaching (Chism, 1999).

When working with these student work products, the focus is not on an individual student. Rather, attention should be paid to overall findings, patterns within class, and, when available, changes over time. For example, by 
determining areas where many students are not achieving, a faculty member can better see where (and why) to modify teaching methodologies. This is not the same process that a faculty member would go through in terms of grading; however, the faculty member is looking at the data at the course level, not the student level. If possible, have the faculty member look across anonymous student work to see the patterns or the areas where many students are missing information.

Other course-specific measures include SGID results, course evaluations, or focus group outcomes. These can help a faculty member to gauge student perceptions to determine where the course needs to be modified, but without actually having specific student learning outcomes, student perceptions can only give part of the necessary picture.

\section{Department-Level Outcome Measures}

Many departments may have some type of an achievement test that is given to seniors or may collect departmental portfolio data. By determining which areas indicate lower levels of achievement, a faculty member can use that information for his or her course in the same manner as outlined in the section above. The advantage to looking at the broader departmental picture is that it becomes easier to see an individual course as a part of a program of study (the way a student sees it). In addition, by using departmental-level data to look at a particular course, a faculty member is demonstrating the need for using existing assessment data. This has great benefit to the individual faculty member and may benefit the department as a whole by "establish[ing] talking about teaching and documenting teaching practices as a normal part of the life of the department" (Gibbs, 1999, p. 152). Faculty developers can encourage this by asking about departmental data when working with an individual faculty member.

\section{Importance of Gathering and Using EfFective FeEdback}

Feedback is an essential part of the learning process, both for students and for faculty who are interested in enhancing their teaching. "Useful feedback lets you know not only how you are doing, but what you should do next to improve" (Huba \& Freed, 2000, p. 122). Meaningful feedback should help point a faculty member in the right direction in terms of what parts of a course or a teaching methodology to focus on first. Without this assessment data, making changes in a course is just a shot in the dark. 
Given the importance of feedback, it is surprising how often faculty have to be prompted to gather information or how often they dismiss the data that is collected. Chaffee (1997) has stated,

compared with other kinds of enterprise, universities and colleges are systematically deprived of input from the people we serve... we typically have a weak system, with end-of-term surveys, if that-too late to improve a course while the student is still enrolled in it." (p. 46)

But it is this feedback (assessment data) that is required if faculty development is going to have meaningful and reliable impact on student learning. According to Brinko (1993), "among all instructional development efforts, the most promising way of fundamentally changing postsecondary teaching is to provide faculty with individualized formative feedback" (p. 574). She goes on to say that "this method... has not been consistently successful, possibly because many who feed back the information to the teacher are not trained in feedback-giving practice" (p. 474). Faculty developers should be adept at working with faculty to gather feedback, feeding back information to faculty and helping them to appropriately interpret the data and, when necessary, choosing a way to implement their interpretations in order to improve student learning. Evidence indicates that the use of appropriate types of consultations does positively affect the changes that a faculty member chooses to make (Cohen \& Herr, 1982; McKeachie et al., 1980).

According to Brinko (1993), data should be gathered from multiple sources. This helps to ensure the validity of the data collected, but it also helps the faculty member to see that a particular issue is not just coming from angry student comments. In addition, one of the sources of data collection should be from the faculty member. There are a variety of ways of collecting self-reflection and self-assessmene from the faculty member (teaching portfolios, self-assessments made after a specific course, or focusing on a specific course objective, etc.). This self-assessment part of the data collection can be especially powerful.

Perhaps this positive attitude results in part from the stimulation of cognitive dissonance created by discrepancies between feedback recipients' self-ratings and feedback sources' assessments. In any case, if the cognitive dissonance is not too large or too small, it is likely to facilitate a change in behavior. (Brinko, 1993, p. 577) 
Brinko also indicated that "feedback is more effective when mediated by a consultant" (p. 577), which points directly to the need for faculty developers to work with faculty in collecting and feeding back information regarding teaching issues.

\section{The Relationship Between Faculty Development Centers and Assessment Offices}

While it is clear that using assessment results will benefit the work of the faculty member, students, and faculty developers, there are interesting findings that faculty who participate in faculty development activities are more likely to "assume ownership of institutional and departmental assessment programs" (Lopez, 1999, p. 17).

Lopez (1999) gathered information from institutional self-study and North Central Association accreditation reports and has indicated that one of the major problems at institutions regarding assessment is the lack of faculty support and participation. However, by working to educate faculty members about the uses and benefits of assessment, it has been possible to gain a "knowledgeable, enthusiastic cadre of faculty who are actively engaged in all aspects of the assessment program" (p. 17). Thus, she sees "faculty development as the primary solution to problems in faculty participation in assessment" (p. 17).

In a way, this highlights the strength of using data in faculty development conversations: Faculty may see the power of using data, first as a benchmark, but then as a regular part of the teaching and learning process. When decisionmaking about teaching issues becomes data-driven, there is a continuous need to gather meaningful information and to ask deeper and more meaningful questions about student learning. When questions are regularly asked and answered about student learning, "faculty members within the academic department can use the resulting data to make substantive and (relatively) immediate changes in course design, course sequencing, [and teaching methodologies] (Wehlburg, 2000, p. 20).

\section{Conclusions}

By tapping into already existing assessment data and encouraging faculty to gather data on student learning outcomes, faculty devclopers can promore effective teaching changes leading to increased student learning outcomes. Assessment data can then become yet another tool to use in faculty development co continue to improve and enhance reaching and learning in higher education. 


\section{REFERENCES}

Angelo, T. A., \& Cross, P. K. (1993). Classroom assessment tecloniques: $A$ bandbook for college ieachers (2nd ed.). San Francisco, CA: Jossey-Bass.

Banta, T. W., \& Associates. (1993). Making a difference: Outcomes of a decade of assessment in higher education. San Francisco, CA: Jossey-Bass.

Bers, T. H., Davis, D., \& Taylor, B. (2000). The use of syllabi in assessments: Unobtrusive indicators and tools for faculty development. Assessment Update, 12, 4-7.

Brinko, K. T. (1993). The practice of giving feedback to improving teaching: What is effective? Journal of Higher Education, 64, 575-593.

Chaffee, E. E. (1997). Listening to the people you serve. In B. L. Cambridge (Ed.), Assessing impact: Evidence and action (pp. 41-50). Washington, DC: American Association for Higher Education.

Chism, N. V. N. (1999). Peer review of reaching: A sourcebook. Bolton, MA: Anker.

Cohen, P. A., \& Herr, G. (1982). Using an interactive feedback procedure to improve college teaching. Teaching of Psychology, 9, 138-140.

Cross, K. P. (1993, February/March). Involving faculty in TQU. AACC Journal, 15-20.

Ewell, P. (2002). Perpetual movement: Assessment after twenty years. Paper presented at the American Association for Higher Education Assessment Conference, Boston, MA. Retrieved May 6, 2004, from http://www.aahe.org/assessment/2002/ PlenariesForFrames.hem

Gibbs, G. (1999). Improving teaching, learning, and assessment. Journal of Geography in Higher Education, 23, 147-155.

Gillespic, K. H., Hilsen, L. R., \& Wadsworth, E.C. (Eds.). (2002). A guide to faculty development: Practical advice, examples, and resources. Bolcon, MA: Anker.

Huba, M. E., \& Freed, J. E. (2000). Leamer-centered assessment on college campuses: Shiffing the focus from seaching to learning. Needham Heights, MA: Allyn and Bacon.

Hutchings, P., \& Marchese, T. (1990, September/October). Watching assessment questions, stories, prospects. Change, 22(5), 12-38.

Lopez, C. L. (1999). A decade of assessing student learning: What bave ue learned; what's next?'Chicago, IL: North Central Association of Colleges and Schools Commission on Institutions of Higher Educarion. 
McKeachie, W. J., Lin, Y-G, Daugherty, M., Moffett, M. M., Neigler, C., Nork, J., et al. (1980). Using student ratings and consultation to improve instruction. British Journal of Educational Psychology, 50, 168-174.

Wehlburg, C. M. (2000, Fall). Respecting students and faculty: The need for "intrusive" assessment. The Department Chair, 11(2), 20-22.

Wehlburg, C. M. (2002). More than a thermometer: Using assessment effectively. In G. S. Wheeler (Ed.), Teaching and learning in college: A resource for educators (4th ed., pp. 177-199). Elyria, OH: Info-Tec.

Wilcox, S. (1997). Becoming a faculty developer. In P. Cranton (Ed.), New directions for adult and continuing education: No. 74. Transformative learning in action: Insights from practice (pp. 23-32). San Francisco, CA: Jossey-Bass. 